\title{
Reducing mother to child HIV transmission: a successful experience
}

\author{
A Ouyahia*, M Rais, A Gasmi, S Mechakra, A Lacheheb \\ From Abstracts from International Symposium HIV and Emerging Infectious Diseases 2014 \\ Marseille, France. 21-23 May 2013
}

\section{Background}

Mother-to-child transmission of HIV remains the main source of pediatric HIV infection, women constituted $50 \%$ of infected people in Algeria, mostly in the reproductive age group.

\section{Objectives}

Mandatory HIV screening in pregnancy, as part of motherto-child transmission (MTCT) prevention, is useful to increase the number of patients under follow-up. Our work aimed to describe MTCT prevention interventions and outcome of newborns during 24-months follow-up.

\section{Methods}

From 99 HIV women followed between 2002 and 2013 to the HIV unit of the teaching hospital of Setif, 10 pregnant women were identified. Pregnancies and deliveries (over 15 days) that occurred before referral to our institution were excluded from the study.

We used data collected in the patients' medical files, Epi info 3.5 version was used for statistical analysis.

\section{Results}

10 mothers had 14 pregnancies, resulting in a total of 14 live born children.

The median age was 19.5 years, 7 were married and 3 were single. The most frequent transmission route was heterosexual (90\%). 3/10 fathers were unaware of HIV maternal status.

$70 \%$ had been previously diagnosed with HIV. All had HAART as MTCT prevention, with $\mathrm{AZT}+3 \mathrm{TC}+\mathrm{LPV} / \mathrm{r}$; median viral load (VL) at delivery was below $1000 \mathrm{cp} / \mathrm{mL}$ in $100 \%$ of patients. Cesaerean-section was performed in $28.5 \%$ of deliveries.

Ferhat Abbes University, Medicine Faculty, Setif, Algeria
3 women were diagnosed after vaginal delivery, PMTCT started in post partum, median viral load after delivery was $7800 \mathrm{cp} / \mathrm{mL}$. All neonates benefited of post natal antiretroviral prophylaxis (AZT during 6 weeks) and fed with formula milk. Mean newborn weight was $3030 \mathrm{~g}$ and HIV-PCR at birth, 3 months, 6 months of age was negative in 13 infants. All mother-infant pairs maintained follow-up at 24 months except for one child who died at 6 months age.

\section{Conclusion}

This important reduction in MTCT is a result of antenatal diagnosis and provision of antiretroviral prophylaxis and treatment for mothers and infants. It highlights the necessity of revisiting the debate of voluntary versus mandatory HIV/AIDS testing during pregnancy.

Published: 23 May 2014

doi:10.1186/1471-2334-14-S2-P35

Cite this article as: Ouyahia et al:: Reducing mother to child HIV transmission: a successful experience. BMC Infectious Diseases 201414 (Suppl 2):P35.

Submit your next manuscript to BioMed Central and take full advantage of:

- Convenient online submission

- Thorough peer review

- No space constraints or color figure charges

- Immediate publication on acceptance

- Inclusion in PubMed, CAS, Scopus and Google Scholar

- Research which is freely available for redistribution 